\title{
GEOHERITAGE SITES THAT ARE IN DANGER AND SITES THAT NO LONGER EXIST IN NORTH MACEDONIA
}

DOI: http://dx.doi.org/10.18509/GBP.2019.08

UDC: 911.52:[502.14:504.61(497.7)

\begin{abstract}
Anita Todorova
Dragan Kolchakovski

University of „Ss Cyril and Methodius”-Skopje, Faculty of natural sciences and mathematics, Institute of geography, Skopje, North Macedonia
\end{abstract}

\begin{abstract}
Although the North Macedonia occupies a relatively small area of $25713 \mathrm{~km}^{2}$, it possesses a large number of geological, geomorphological and hydrological relief forms, which due to its diversity and uniqueness are prominent as important the geoheritage sites. A large percentage of geoheritage sites are exposed to destruction or complete disappearance, and as the main factor for this are the various natural processes and human activities. This paper analyzes the several examples in danger and no longer exist geoheritage sites on the territory of North Macedonia, the level of threat and their protection. In order to stop the further degradation of the remaining geoheritage sites it is necessary to take appropriate measures of protection and adequate management of the geoheritage by the state and local governments. To ensure long-term survival of geoheritage sites as paramount priority is to perform adequate protection regulated by law.
\end{abstract}

Keywords: degradation, protection, geoheritage sites, North Macedonia

\section{INTRODUCTION}

The processes and phenomena that nature forms with its diversity, rarity, and representativity create a particular interest in people to explore and visit, and similarly to the needs for their protection. The geodiversity affected by various natural and anthropogenic processes may be a subject to degradation or total destruction. Geodiversity is defined here as the range (or diversity) of geological (bedrock), geomorphological (landform) and soil features, assemblages, systems and processes [23]. The components of geodiversity that are important to the people in terms of different types of uses, apart from utilization as resources and objects, should be kept for the present and future generations [7]. The occurrences and shapes separated from geodiversity that are of great importance for humanity create the geoheritage. The term geoheritage is used to refer to globally, nationally, state-wide, regional, to local features of geology, such as its igneous, metamorphic, sedimentary, stratigraphic, structural, geochemical, mineralogical, palaeontologic, geomorphic, pedologic, and hydrologic attributes, at all scales, that are intrinsically important sites, or culturally important sites, that offer information or insights into the formation or evolution of the Earth, or in the history of science, or that can be used for research, teaching, or reference [1]. As a result of the conditions and developments in the various epochs of the geological history, the geodiversity on the territory of North Macedonia is characterized by the many specifications and significant complicity. Because of this, a number of geological, geomorphologic and hydrological relief forms are distinguished, which due to their 
diversity and uniqueness are distinguished as important geoheritage sites. A large percentage of the geoheritage sites are exposed to destruction or complete disappearance, and as the main factor for this are the various natural processes and human activities that contribute to all that. In this paper, several geoheritage sites are being presented, defining the degree of their threat and the level of their endangerment and several other sites that no longer exist, and as the main factor for this is the human factor. Therefore, it is necessary to stop the further degradation of the geoheritage sites and to take adequate measures for their protection which will be regulated by law.

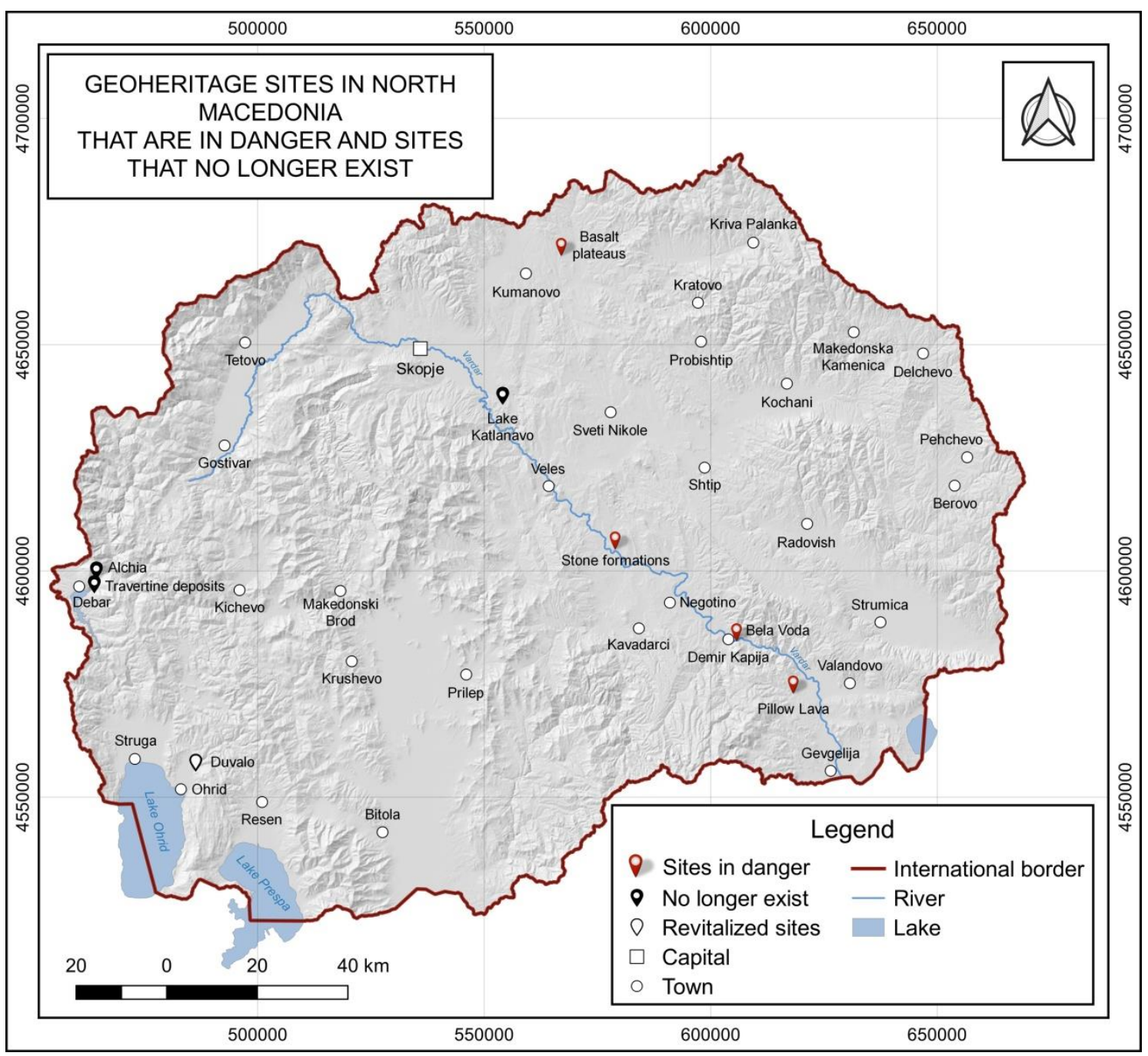

Figure 1. Location of the geoheritage sites that are in danger, sites that no longer exist and revitalized site

\section{THREATS TOWARDS THE GEOHERITAGE SITES}

Many authors consider that a lot of attention is paid to the protection of biodiversity, rather than geodiversity. This is logical because biodiversity is sensible and vulnerable and therefore needs protection, while for the abiotic nature, such as mountains and rocks, it is thought that they are stable, solid and more represented, and for that reason they are not endangered [10][18]. This point of view is already overlooked because there are many geodiversity threats. When talking about endangerment or threats to geodiversity, it is not just about the physical damage and the exploitation of physical material, but also the 
obstruction of the geological, geomorphologic and pedological processes which is very subtle and not so impressive. The most dangerous factor for the destruction of geodiversity are the activities of the people, so-called artificial factors [10][11].This is considered to be the increasing trend of settlement development (urbanization, infra-and sub-structure) and land use [9]. The human impact results in the destruction or damage of important rocks, minerals or fossils, remodeling the natural topography, interrupting the natural processes [5]. The most common activities in the geoheritage sites are tourism, forestry, agriculture, water management, hunting and fishing, various types of recreation, fruit harvesting and beekeeping. Tourism is mostly covered in these sites due to their natural beauty, but nevertheless adversely also affects them. In these areas, infrastructure facilities are being built to serve tourists. The low level of environmental education, the negligence of tourists on nature affects the disturbance of the natural ambient. There are many important activities that need to be studied better in protecting geodiversity in a better and more efficient manner. The impact of these activities and threats may vary depending on the elements of geodiversity, that is, its sensitivity, hardness and size [22]. According to Gray [10], human (negative) influences of geodiversity can be classified as follows: complete loss of an element of geodiversity, partial loss or physical damage, fragmentation of interest, loss of visibility or intervisibility, loss of access, interruption of natural processes and off-site impacts, pollution, visual impact. A more detailed classification of the threats to geodiversity has been made by Natural England [12]: inadequate development, natural degradation, irresponsible collection of samples, irresponsible recreational activities. Although the threats and values of geodiversity are gaining more international recognition, the threats to it are still not recognizable at the same level as in the case of biodiversity [28]. The risk of degradation of geoheritage sites can be defined as sensitivity, fragility and vulnerability. The sensitivity of a geosite is the geosite's susceptibility to damage or destruction, i.e., the likelihood that the geosite's natural characteristics will be damaged or destroyed. It is important to note that natural characteristics of a geosite can predispose it to damage or destruction from both natural and anthropogenic factors. Fragility is defined here as the sensitivity of a geosite to being damaged or destroyed by intrinsic factors. They are linked to a temporal scale. The vulnerability is defined as the sensitivity of a geosite to being damaged or destroyed by extrinsic factors that are natural or anthropogenic in origin. Thus, two types of vulnerability are being considered: natural vulnerability and anthropogenic vulnerability. The public use context of a geosite determines the probability that it will be damaged or destroyed by being used (eg, its proximity to cities or important roads, its accessibility or the number of visitors) [8].

\section{PROTECTION OF THE GEOHERITAGE SITES}

By the fact that the diversity of geoheritage sites is remarkably large - from one crystal to the whole mountain area, the question of the way of their protection becomes more significant. The various natural processes and influences of the human population can negatively affect the geoheritage sites, that is, they are degraded or completely destroyed. After their identification as geoheritage sites, their conservation or protection should be carried out completely. The implementation of the geo-conservation maintains significant representative phenomena and processes of geodiversity, such as rocks, landscapes, soil characteristics, etc. Conservation refers to the protection and management of natural "goods". Geodiversity should be preserved for two main reasons [10]: because of its numerous values (intrinsic, aesthetic, scientific, cultural, etc.) and because of the many 
human-made threats. Many authors have been engaged in defining the term geoconservation. Sharples [23] gave one of the first definitions of geoconservation and the conservation of geodiversity for its intrinsic, ecological and geoheritage values. Furthermore, Eberhard [7] gave a more comprehensive definition in 1997 and says: identification and conservation of geological, geomorphological and pedological phenomena, systems and processes (geodiversity) due to their intrinsic, ecological values and geoheritage. The conservation is considered to be active management of geodiversity sites and maintaining their quality, and not pure and strict protection of phenomena, locality or processes. In recent literature geoconservation can be defined as the action taken with the intent of conserving and enhancing geological and geomorphological features, processes, sites and specimens [2]. Geoconservation is the preservation of the special geological areas (samples) used for scientific research, education and training, where popularization of Earth's history for the general public is needed in order for better conservation practice. Geoconservation includes protection, physical management and improvement of geo-regions of international and national importance for the purpose of scientific and educational exploitation [19]. The geoheritage sites can be protected in situ or isolated from it ex-situ. There are two types of conservation or protection of the geoheritage sites: physical protection and combined physical protection and conservation / protection from the factors of degradation. They can be: protection against adverse effects of natural geological-geochemical factors and protection against adverse effects of anthropogenic-geological factors [4].

In order to preserve the natural values in the protected areas it is necessary to provide adequate protection regime. The regime for the protection of natural values of protected areas is regulated by law. There are two types of measures: prohibitions that are clearly defined, recognizable and unique to application, and restrictions on acceptable activities [27]. The goal of geoconservation is to preserve the natural geodiversity, i.e. the important geological (rocks), geomorphologic (relief form) and pedological phenomena and processes, thereby preserving the natural speed and significance of those processes and phenomena.

\section{THE GEOHERITAGE SITES THAT NO LONGER EXIST}

\section{Travertine deposits at the spring called Kosovrasti}

The travertine deposits were located near the Kosovrasti village in the lowest river terrace of the river Radika. These deposits are a consequence of the chemical action of atmospheric and thermal water in gypsum. As a result of the dissolving effect in the thermal water that formed from the inside of the gypsum mass on the surface itself, it formed chemical accumulative forms i.e. travertine deposits [20]. These travertine deposits were submerged with the construction of the artificial accumulation Shpilje or lake Debar in 1969. 


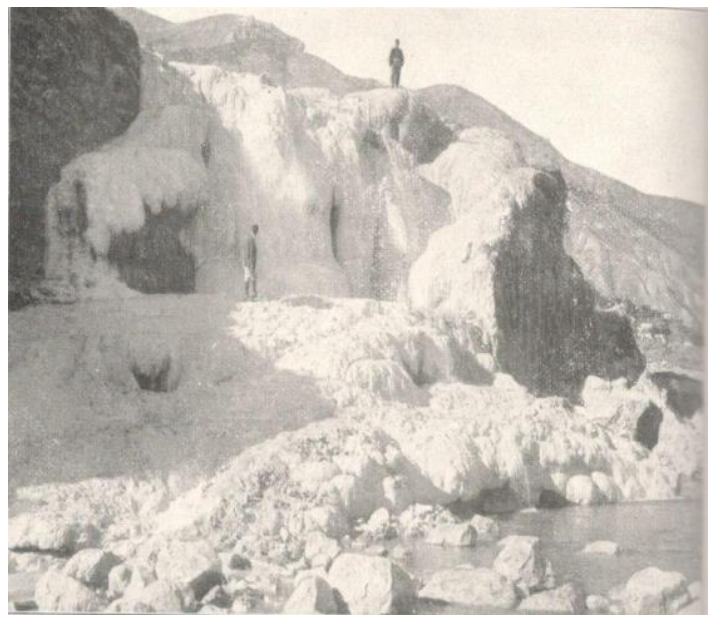

Figure 2, Travertine deposits

[20]

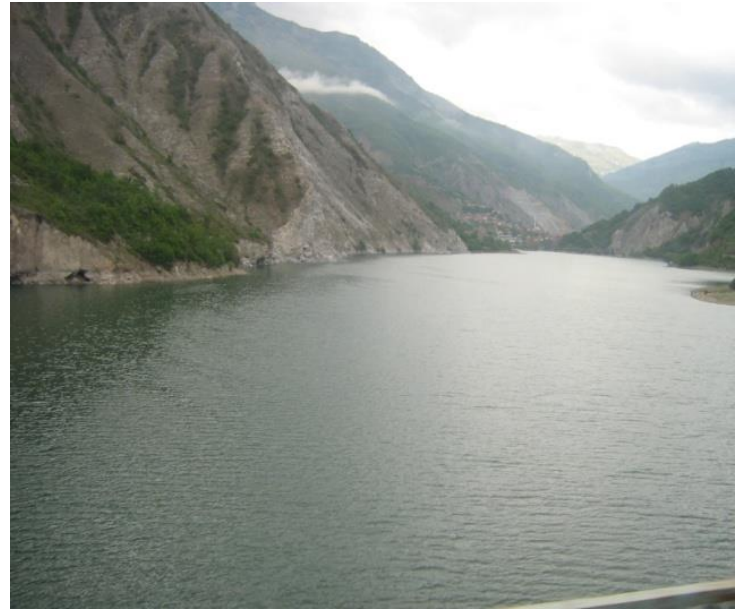

Figure 3, lake Debar (photo: Todorova)

\section{Gypsum cave-Alchia}

The cave is located on the southern slopes of Krchin, on the right valley side of the river Radika about $8 \mathrm{~km}$ east of city of Debar. It is located at an altitude of about $740 \mathrm{~m}$. It was named after the Turkish word Alchi which means gypsum. The appearance of the cave is closely related to the genesis of natural gypsum deposits. The cave according to the way of creation represents a rarity. From the entrance of the cave the canal gradually expands and then opens a large hall with an egg-shape. The canal is $90 \mathrm{~m}$ long and 2-4 $\mathrm{m}$ wide.

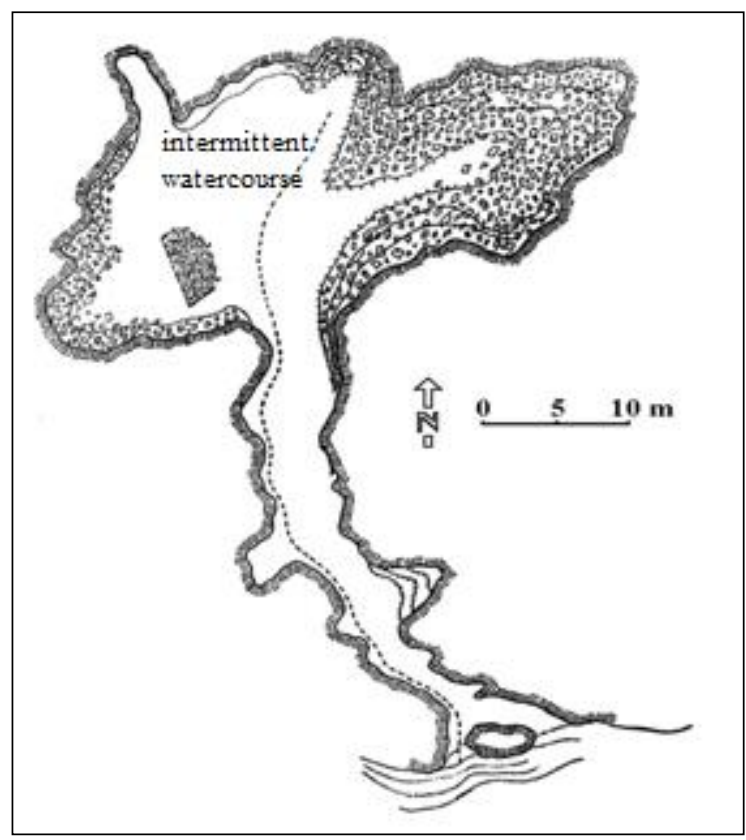

Figure 4. A plan of the cave Alchia

[24]

The maximum height of the hall is $10 \mathrm{~m}$ [24]. With the exploitation of gypsum from the cave, the dimensions of the canal have significantly increased. On the east side of the hall there are small blocks of crystal gypsum and alabaster. In the middle part of the hall there is another block of crystal gypsum and alabaster, which is a result of the former 
exploitation of gypsum. This cave has been used for a long time as an exploitation mine for alabaster where exploitation was unorganized by individuals. Today this cave has insignificant features from its original natural appearance. On the walls of several places there are marks from mining explosive mines. There are no nicely shaped stalactites in the cave. Stalactites in their initial form of appearance appear on the ceiling and on the slanting side walls. The floor in the cave is flattened due to the easy exploitation of the gypsum. In the cave there is no permanent watercourse [24]. The cave Alchia is the only cave built in gypsum on the Balkan Peninsula, but due to the exploitation of gypsum it no longer exists as it was in the initial natural setting.

\section{Lake Katlanovo}

The Lake Katlanovo was located in the southeastern part of the Skopje valley, between the river Pchinja and the entrance of the river Vardar in the Taor gorge. It began with the rise of the riverbed of Vardar with a layer of sediment that flooded the water that flowed into the river Vardar from the north side. Between the lake and the river Vardar there was the riverbed of the river Mrkvica, where through it during high water the river Vardar flew off into the lake Katlanovo. The lake had an area of 4, $24 \mathrm{~km}^{2}$, and with the overflow of the river into the lake the surface increased to $10 \mathrm{~km}^{2}$ [25]. After 1930, significant land melioration works were done where the lake was brought to pre-drying. The Katlanovo Marsh is part of the former neogene lake Katlanovo.

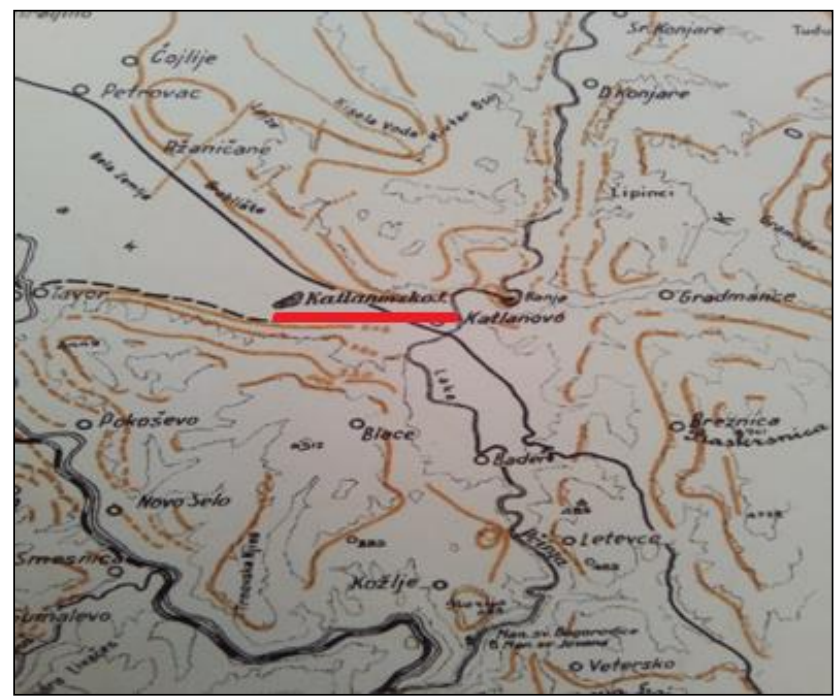

Figure 5. Location on former neogene lake Katlanovo

[14]

\section{IN DANGER GEOHERITAGE SITES}

\section{The site basalt plateaus}

This site is located in the northeastern part of North Macedonia, near the village of Mlado Nagoricane. In its geological evolution, the territory of North Macedonia was characterized by a large volcanic activity. This site belongs to the Kumanovo-Sveti Nikole volcanic area. Volcanoes in this area were of a linear type that were located at the places of deep structures where basic lava used to drain out of them. The leakage of the lava was slow and as a result of that a plateau was formed. The neotectonic movements and erosion affected the separation of the only plateau. This resulted in the only plateau decoupling and forming more small plateaus. In this space the plateau was divided into 
eight smaller plateaus a height of 50-80 meters [15]. The plateaus are composed of chunky blackish basalt, and in some of them there are red layers of a very light sponge mass of lava. The largest of these basalt plateaus is the plateau called Tsabernik, the smaller of which is the Middle Stone, and the smallest one is the basalt plateau called Ostrovitsa [3]. During the field research, it was noted that on one basalt plateau there were wire lines and a substation. This threatens the original natural ambience of the site.

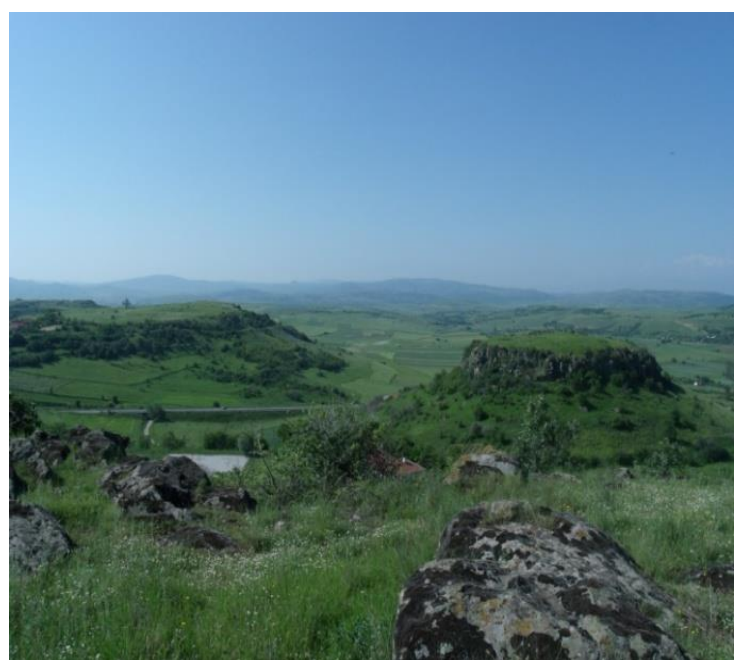

Figure 6. The basalt plateaus

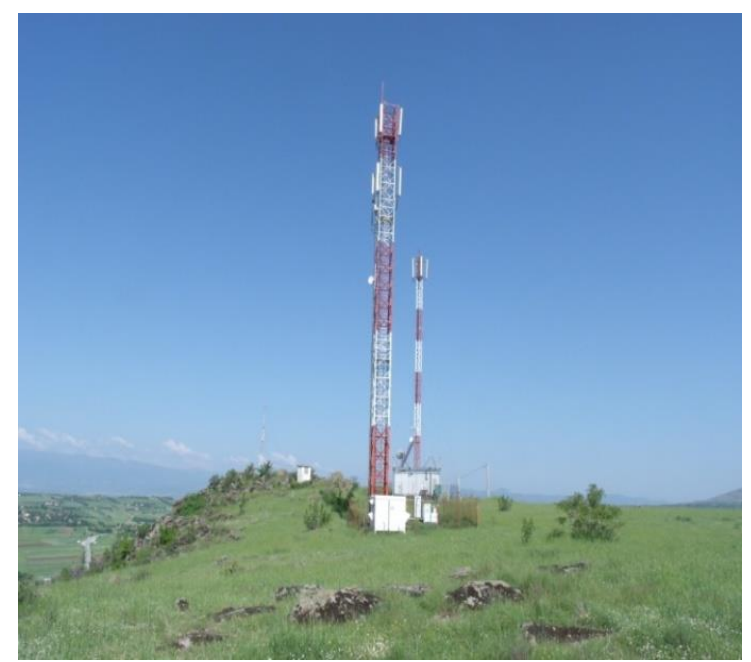

Figure 7. A basalt plateau with wire lines and a substation

(Photo: Todorova)

\section{The cave „Bela Voda”}

Near the Demir Kapija Gorge, on the right side of the river Vardar is the Bela Voda cave, which is has the length of 955 meters and built in limestone from Jurassic age. Its entrance is on the road that used to be used to reach the city of Gevgelija. The entrance has a width of about 1, $2 \mathrm{~m}$ and a height of about one meter. It is composed of two canals, an upper and a lower canal, where the upper canal has a length of $233 \mathrm{~m}$, and the lower canal has a length of $722 \mathrm{~m}$. After the entrance, it goes to the canal where it is divided into two parts. The right part today is covered with blocks. The left part belongs to the main canal. After $9 \mathrm{~m}$, the main canal extends to two openings from where there is a slight turn and you will reach the first small hall. After the hall, through the main canal over the compartment of 2, $5 \mathrm{~m}$, you are entering the large hall. This part was a remnant of a former siphon. The big hall is composed of two parts. The right part is $4 \mathrm{~m}$ wide, but it narrows down after $14 \mathrm{~m} \mathrm{[17].} \mathrm{The} \mathrm{left} \mathrm{one} \mathrm{is} \mathrm{a} \mathrm{continuation} \mathrm{of} \mathrm{the} \mathrm{main} \mathrm{canal.} \mathrm{There} \mathrm{are} \mathrm{three}$ plunge pools on the main canal. After that, the main canal continues in the southsouthwest direction. The height of the canal is almost the same, but in some parts it decreases. The main canal is divided into an upper and lower canal. The lower channel is a continuation from the main canal. After a few meters, the two canals are merged with vertical canals. At the end of the lower canal there is an underground natural canal filled with water. It's Margaritino Lake. This lake belongs to the group of gravital basins. The lake is $8 \mathrm{~m}$ long, $4,5 \mathrm{~m}$ wide and 4,5 $\mathrm{m}$ deep in the middle and $5 \mathrm{~m}$ in the end [17]. The cave Bela Voda is a young cave and as a result of that it is poor with cave decorations. The cave is inhabited by a large number of invertebrates, as well as unusual species of bats. There are inscriptions on the walls in the cave Bela Voda, which results in endangering the natural process of its formation, that is, for the formation of cave 
decorations. The irresponsible and deviant behavior in the cave also endangers the cave fauna too.

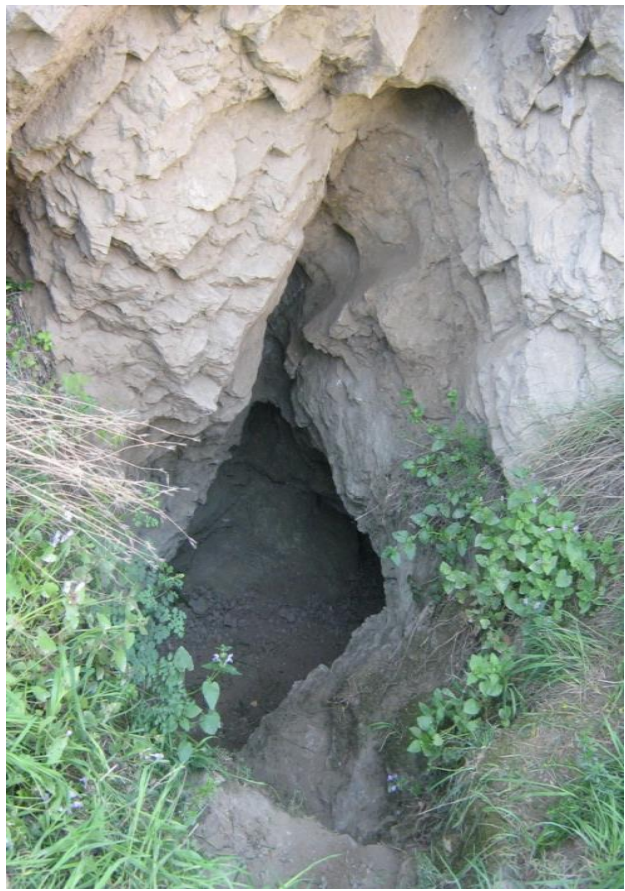

Figure 8. Entrance on the cave Bela Voda

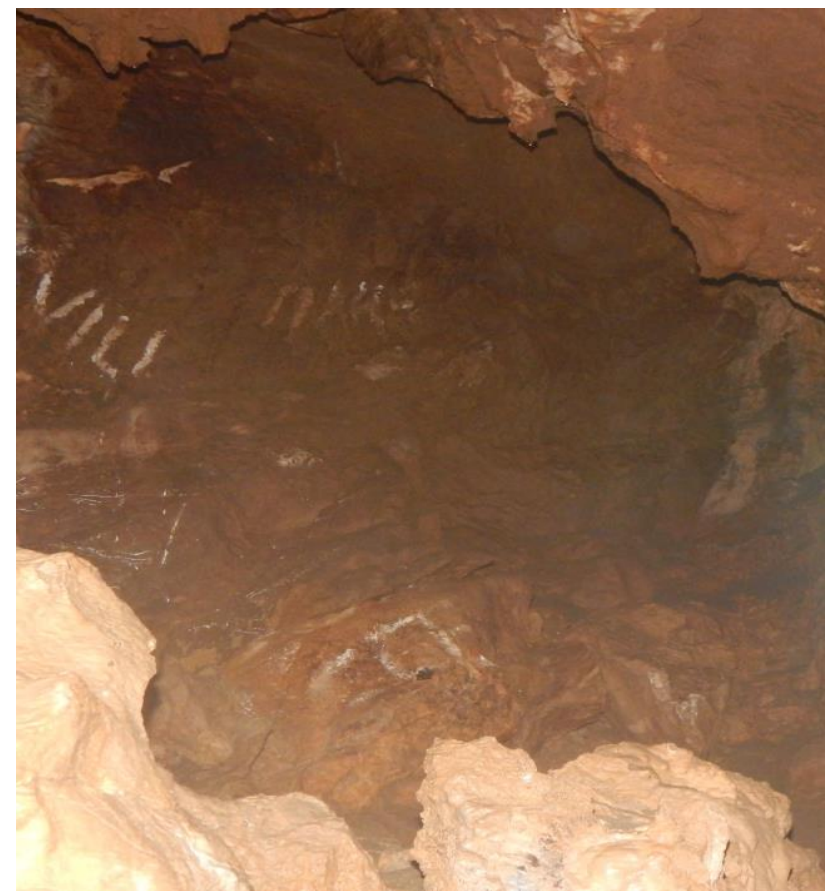

Figure 9. Inscriptions on the walls in the cave (photo: Todorova)

\section{The site with stone formation with the ball and plate-shaped-ulanci}

The site with stone formation with the ball and plate-shaped is located to the eastnortheast of the village of Ulanci. The stone formation with the ball-shaped are located directly to the east of the village, while the stone formation with the plate-shaped are encountered in a slightly eroded hill, northeast of the village of Ulanci at the elevation Rid (196 m) 160-170 m above sea level. The geological composition of the hill Rid (196 $\mathrm{m}$ ) is composed of a thick layer of quartz gravel which contains gravel, besides the gravel there is also gneiss, amphibolite gneiss, amphibolites, gabbro and other various types of rocks. On the southeast side of the flat surfaced Rid above the village road, leading through Vardar in the Paleocene flysch series, gray tiny sandstones prevail, and instead of the clay rocks, there are more of the marls here. In the alternate series of these layers, the appearance of the stone formation with the ball-shaped is typical, which with its crawling on the valley side provides such an unusual look. Their shape gives them a look of balloon erosive and denudation blocks; in fact it was their primary form. These are true sand-marl shapes composed of a Paleocene flysch series that by eroding and denudation of the lower layers fall behind these as resistant rocky balls [21]. These sandy spherical shapes are not uniformly equal, neither in shape nor in size. They can be found as completely in round shape and form, but also more in a shape of an egg, there are also ones that turn into the shape of a more or less growing „bread”. In addition, the stone formation with the ball-shaped have a diameter of $10 \mathrm{~cm}$, some with $30 \mathrm{~cm}$, but there are also those with a diameter of $50 \mathrm{~cm}$. In this side of the valley, frequent processes of perennial denudation and erosion can be noticed and seen, and as a result, the sandstones, marls and unbound sand were eroding significantly, and the sandy-marls forms remained exposed in the stone formation with the ball and plate-shaped because they were firmer 
and more resistant to erosion and denudation unlike the neighboring rocks. Depending on their texture, these sandy-marls forms with a plate- shaped, during the outflow from the bearings, as well as in the subsequent decays, they receive their spherical ball shape. In this way, they are being separated from the flishy rock masses, and as a result they gradually disappear. Interesting about these sandy-marls forms in the form of plates is their cracked spread, north-south, and east-west with a slight turn of $10^{\circ}$ towards the northeast of the underlying creek. During field surveys, about 50 such forms were observed, and when measuring them, those with a diameter of $70-75 \mathrm{~cm}$ and $100-102 \mathrm{~cm}$ were being measured. Among stone formation with the ball-shaped there are those that are newly discovered and still very solid, but there are also those who succumb to the destruction of the land and are destroyed so new can emerge in their place, and with the denudation process to be discovered. During the field research, it was noticed that an earthen road is passing through the stone formation with the plate-shaped, which signifies a threat for their further damaging.

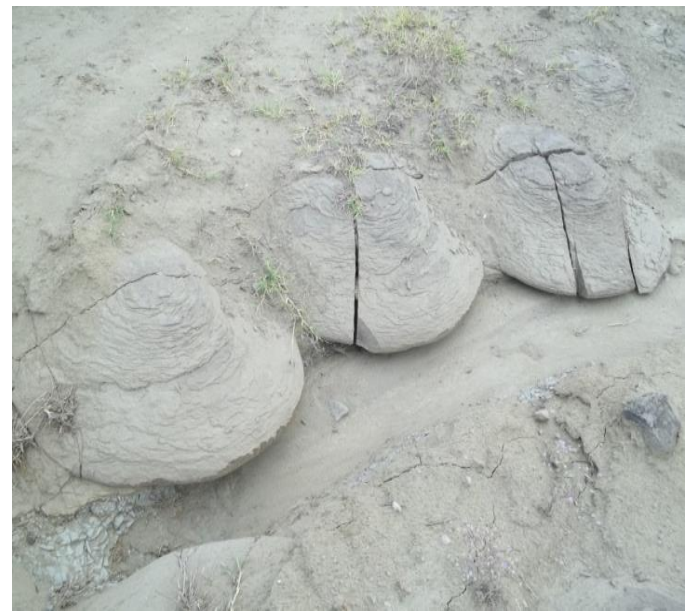

Figure 10. Stone formation with plate-shaped

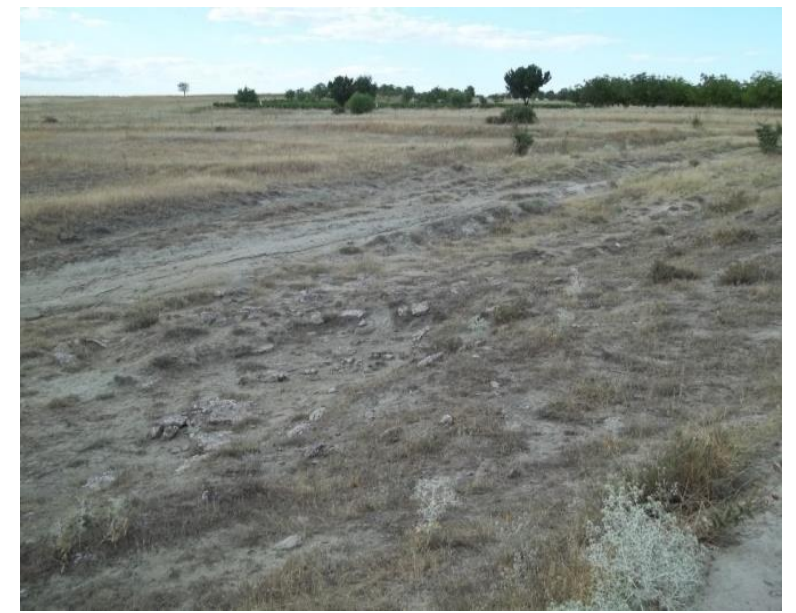

Fugure 11. The earthen road near the stone formation with plate-shaped

(photo: Todorova)

\section{The site called Pillow Lava}

The site called Pillow Lava (among the locals this locality is known as the „White Paradise") is located southwest of the settlement Miravci. It covers the eastern slopes of the mountain Kozhuf, at $185 \mathrm{~m}$ above sea level, that is, the inflow of Stara Reka into Petrushka Reka. The Pillow lava, or magmatites (spilits), was built as a result of the Triassic-Jurassic magmatism, or as a result of the excretion of magma into an aquatic environment. There was a gravelly secretion as a result of the unequal temperature of the lava and the water, and the rocks themselves received ellipsoidal forms. Such rocks can be seen along the highway E-75 on the section Demir Kapija-Udovo and near the settlement of Miravci. By the fluvial erosion of Stara Reka and Petrushka Reka they are manifested on the surface of the terrain [16].

At the inflow of Stara Reka into Petrushka Reka, at the connetion itself, both rivers have created small gorge with canyon characteristics which are $13 \mathrm{~m}$ high. Through the course of Stara Reka, the unequal crossing from three cascades and two waterfalls with $500 \mathrm{~m}$ distance between them. The first cascade has a length of $9,2 \mathrm{~m}$, and at the bottom has formed the plunge pool. The formed plunge pool is $11 \mathrm{~m}$ wide and $3 \mathrm{~m}$ deep. Downstream of the river course at a distance of $30 \mathrm{~m}$ after the first cascade, a second cascade with a 
length of 8,2 $\mathrm{m}$ has been formed. After the second cascade, another cascade has formed, which has a length of $3.3 \mathrm{~m}$. Immediately after the three cascades, at a distance of $8 \mathrm{~m}$, there is a waterfall with a height of $5.3 \mathrm{~m}$, and several meters downstream there is a second waterfall with a height of $7 \mathrm{~m}$. Here, another plunge pool is formed, which, unlike the first one, is larger and has a width of $10 \mathrm{~m}$, a length of $13 \mathrm{~m}$ and a depth of $3.5 \mathrm{~m} \mathrm{[26].}$ During the field research, it was found out that on the site a catering facility had been built that has changed the ambience by adding bridges of iron, wood and stone and also polluting the water.

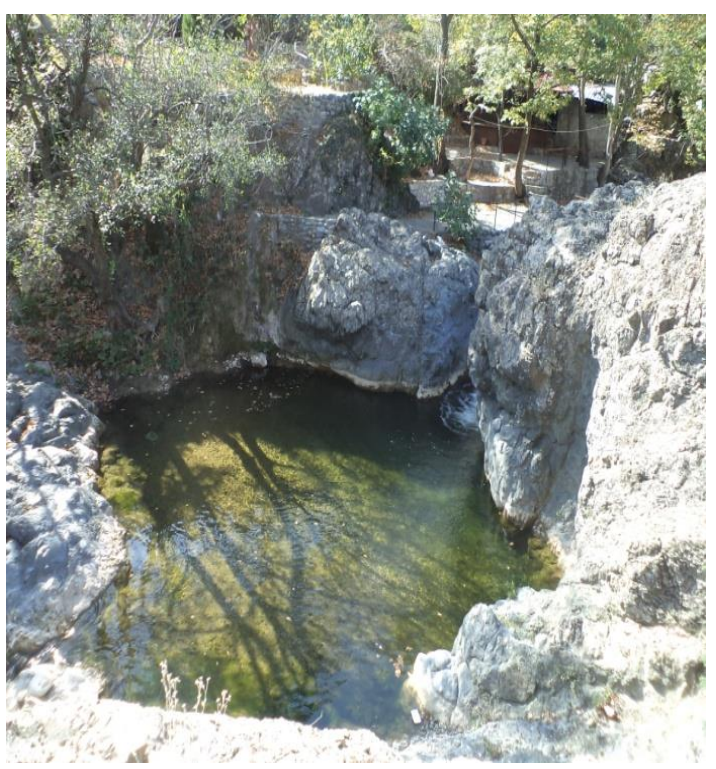

Figure 12. The first plunge pool

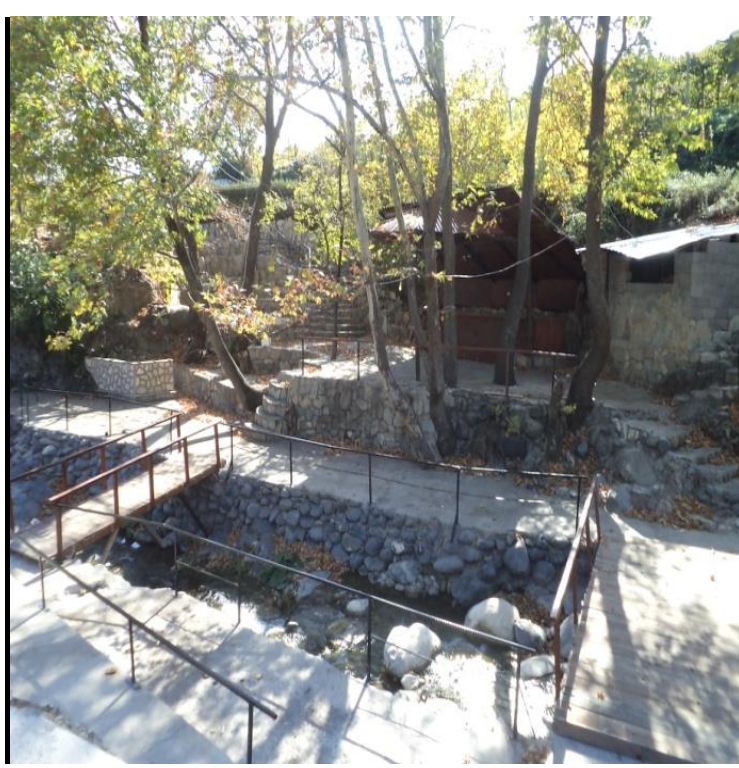

Figure 13. The restaurant at the "Pillow lava" site (photo: Todorova)

\section{REVITALIZED OBJECTS OF THE GEOHERITAGE}

\section{Solfatara Duvalo}

The solfatara Duvalo is located in the southwestern part of North Macedonia in the vicinity of the village of Kosel and stretches northeast of Ohrid. During the Neogene, more precisely during the Eocene, Oligocene and Lower Miocene, the territory of North Macedonia was characterized by great volcanic activity. As a result, several areas of the extinct volcanic activity are being distinguished. One of these areas is the Ohrid-Kosel volcanic area. Here the volcanic activity connects to the system of faults, the most famous of which is the Kosel fault. The phenomenon of palaeo-volcanic appearances, such as fumaroles and solfatara, can be seen in the villages of Pesochani, Vapila, Kosel, Velgoshti. The most famous and most characteristic is the solfatara Duvalo near the village of Kosel. Duvalo is an active palaeo-volcanic phenomenon. It has the appearance of a miniature crater with a diameter of $0.5 \mathrm{~m}$ and a depth of $30 \mathrm{~cm}$ [6]. It lies in a typical crevice with a meridian stretching path. To the north of the solfatara on the eastern slopes of Karaorman, there are several fumaroles and solfatara on the same Kosel spread line that are actually the last occurrence of the once active volcanism in this region. From the aperture of the crater, there are gases of carbon dioxide and sulfur hydrogen at a temperature of $12^{\circ} \mathrm{C}$. The solfatara was abandoned and loaded with waste, so around the area of the solfatara there was a different construction waste and dumping, and all the way to another kind of solid waste. In 2010, the Municipality of Ohrid took the initiative 
to clean up the solfatara Duvalo. According to the annual program for protection of the environment and nature, the sector for urbanism and environmental protection has made the project "Protection and arrangement of the site Duvalo, solfatara in Kosel and its promotion". The project was implemented at the end of 2010. The teams of PE "Ohridski komunalec" cleared the area around the locality Duvalo, that is, large quantities of construction rubble and other types of garbage were cleaned out.

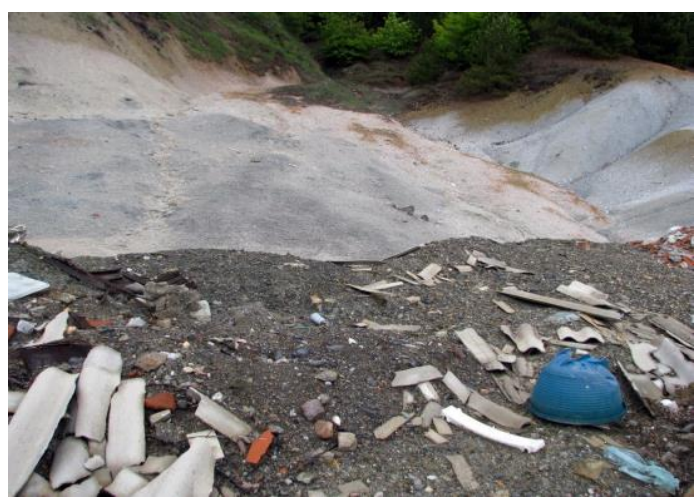

Figure 14. Landfill at the solfatara Duvalo (photo: Kolchakovski)

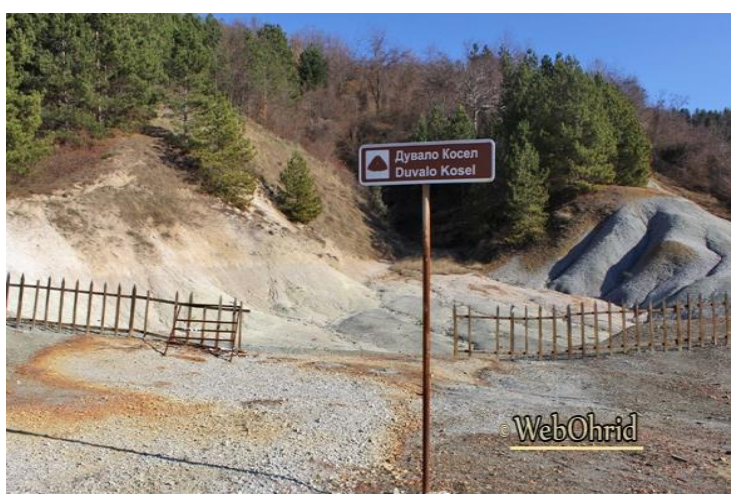

Figure 15. The regulated space in the solfatara

[13]

After that, the road was arranged for an easier access to the site. A protective fence was also placed at the site, so if the visitor stays more than $15 \mathrm{~min}$ at one spot, it may negatively affect its health, and therefore because of the purpose to prevent the craters from destroying. A notice board is set up both on Macedonian and English, which contains the basic data and information for the solfatara Duvalo. Pathways are placed on the main road that goes through the village. Kosel, which show the exact location of solfatara. This site can be placed in the tourist offer of the city of Ohrid and its surroundings. For this, leaflets have already been developed that are already promoting it as a new tourist attraction. This site received the status of a natural rarity by the Assembly of the Municipality of Ohrid and in 1979 it was proclaimed a Monument of Nature.

\section{DISCUSSION AND CONCLUSION}

The researches carried out throughout the XX and XXI century show that there are numerous interesting geological, geomorphologic, hydrological and pedological phenomena on the territory of North Macedonia. Some geoheritage sites are partially or completely destroyed by the action of natural processes or by human activity. The geoheritage sites may also be deleted from the geoheritage list if they are so damaged that they are no longer of any representative value. In this paper, three geoheritage sites were presented that no longer exist, and the main factor for their complete destruction is the human factor. With the construction of the artificial accumulation Shpilje or lake Debar, which is of great importance to man for obtaining electrical energy, it contributed to immersion of travertine deposits and their complete destruction. The exploitation of gypsum from the cave Alchia which is used for construction, it completely destroyed the original natural state of the cave. Due to the prolonged exploitation of gypsum from the cave it is necessary to protect and maintain the current state, therefore the cave is proposed for protection in the category of monument of nature. The meliorative activities that are also in the function of the human have also contributed to the dry out and disappearing of the lake, and as a mute witness for this is the rest of the Neogene Lake Katlanovo Marsh. 
The meliorative human activities continue to pose a threat to Katlanovo Marsh. For this reason, the marsh is protected by law in the category of separate plant and animal species outside the natural reserves in order to stop its destruction. On the territory of North Macedonia, there are several geoheritage sites that are endangered or threatened with their complete destruction, whether from natural processes, or from human negligence or exploitation. A very important factor is the risk of degradation whether they are sensitive, fragile and also their degree of vulnerability. The natural processes that contribute to their destruction cannot be stopped because it is a natural process and occurs over a long period of time, but human degradation can and needs to be stopped and unlike natural processes, it occurs very quickly. Such an example of human negligence is the destruction of the cave decorations. For the occurrence of the caves, forming the cave decorations, the creating of the cave flora and fauna, a timeline of millions of years needs to pass because it's a slow process that needs a lot of time, and on the other hand, for the process of destroying the already created cave decorations it only needs a short period of time. In this paper, four geoheritage sites will be presented which have the human factor as the main factor for their endangerment. On the site Basalt plateaus, the natural landscape is being disturbed by the installation of wire lines and a substation. The site should be protected on the very spot of appearance - in situ. According to the legal regulations, the site is included in the draft law on the proclamation of a monument of nature. This will gain adequate protection in order not to destroy the phenomenon of anthropogenic influences. At the site and in the immediate surroundings the following will be forbidden: digging, crushing or breaking down the basalt rocks, opening a quarry on the site itself, leveling or digging in on the terrain, all kinds of buildings (houses, infrastructure objects), setting up surface power lines over the plateaus, pipelines, gas lines, oil lines, phone lines, etc.), placing advertisers and other types of boards, flags, light inscriptions, and more. The cave Bela Voda is not closed by a door, and this only contributes to providing free access to it. The uncontrolled entering by people into the cave negatively affects the cave fauna and damages the cave walls. The cave is proposed to be protected by law as a monument of nature. A great threat to the stone formation with the ball and plate-shaped of Ulanci is the traced earthen road that passes directly to them, and thus destroys the phenomena. The site should be protected on-site in situ or separated from it - ex situ, that is, to display certain examples in museums or facultative collections. The site is proposed to be protected in the category of monument of nature. Also, of great importance is the geological composition of these phenomena because it is subjective to erosion. With the construction of the catering facility at the site Pillow Lava - Miravci and the use of unnatural material, there is a serious threat to the site and its destruction. It is therefore necessary to stop such construction activities in order not to destroy what was left of this site. It needs to be protected on-site in situ and is proposed to be protected in the category of a monument of nature. The solfatara Duvalo is presented as an example for revitalized geoheritage sites. This is the result of a serious approach by the state and local authorities that, through specific projects stop the destruction of the site and provide long-term survival of the site itself. From this example, others should also be led to stop their destruction, which have the human as the main factor.

Due to the partial or complete destruction of the geoheritage sites, a set of national programs for a complex approach to the problems of the geoheritage should be prepared, and thus conservation plans for protection too. There should also be public panels where the vulnerability of the geoheritage sites will be the subject of duscussion, thereby 
increasing the public awareness of the people in order to keep an eye on the phenomena and processes created by nature.

\section{REFERENCES}

[1] Brocx M. \& Semeniuk V. Geoheritage and geoconservation - history, definition, scope and scale, Journal of the Royal Society of Western Australia , 90, pp 53-87, 2007.

[2] Burek, C. V \& Prosser C. D. The history of geoconservation: an introduction, Geological Society, Special Publications v. 300, London, pp 1-5, 2008.

[3] Cvijich J. Geography and geology basics of Macedonia and Old Serbia, Belgrade, book 1, pp 1-688, 1906.

[4] Dangic A. Geological heritage in Serbia- Identification, categorization and protection of heritage objects, Journal if the Institute for protection of nature of Serbia, Beograd, pp 71-78,1998.

[5] Dimitrovska O. Significance and protection geodiversity, Bulletin of Physical Geography, $\mathrm{n}^{\circ}$ 5, Skopje, pp 77-86, 2008.

[6] Dimitrovska O. Protection of the natural heritage,Skopje, pp 1-110, 2010.

[7] Eberhard, R. Pattern and Process: Towards a Regional Approach to National Estate Assessment of Geodiversity, 1997 Technical Series No. 2, Australian Heritage Commission \& Environment Forest Taskforce, Environment Australia, Canberra, 1997.

[8] Garcia-Ortiz E., Fuertes-Gutierrez I. \& Fernandez-Martinez E. Concepts and terminology for the risk of degradation of geological heritage sites: fragility and natural vulnerability, a case study, Proceedings of the Geologists' Association 125, Elsevier, pp 463-479, 2014.

[9] Gordon, J.E. \& MacFadyen, C.C.J. Earth heritage conservation in Scotland: state, pressures and issues. In Gordon, J.E. \& Leys, K.F. (eds) Earth Science and the Natural Heritage. Stationery Office, Edinburgh, pp 130-144, 2001.

[10] Gray M. Geodiversity, Valuing and Conserving Abiotic Nature, Chichester, John Wiley \& Sons, U.K. pp 1-434, 2004.

[11] Gray, M. Geodiversity and Geoconservation: What, Why and How? George Wright Forum 22(3), pp 4-12, 2005.

[12] http://www.naturalengland.org.uk

[13] http://www.webohrid.com/vo-tek-e-implementacijata-na-proektot-duvalo-od-predizvik-doresenie-promocija-i-zastita-za-odrzliva-zaednica/

[14] Jovanovik P.S. The relief of Skopje Valley, Bulletin of Scientific Society of Skopje, X, Skopje, 1931.

[15] Klincharov S. \& Anastasovski V. Geological and geomorphologic heritage of the Republic of Macedonia, Journal of the Institute for protection of nature of Serbia, $n^{\circ} 48-49$, Belgrade, $p p$ 91-97, 1998.

[16] Kolchakovski D. Recently evidenced localities in the Republic of Macedonia in function of protecting the geodiversity, Bulletin of Physical Geography, no. 7-8, Skopje, pp 15-27, 2011.

[17] Manakovik D. Caves in Demir Kapija, Proceedings of the Geographical Institute SANU LVII- vol. 1, Belgrade, pp 77-93, 1957.

[18] Pemberton, M. Conserving Geodiversity, the Importance of Valuing our Geological Heritage, Paper presented to the Geological Society of Australia National Conference, 2001.

[19] ProGEO. Conservation our shared geo-heritage-a protocol on geoconservation principles, sustainable site use, management, fieldwork, fossil and mineral collecting, Sweden, pp 1-10, 2011. 
[20] Radovanovik V.S. Gypsum relief in Kosovrasti along the Radika valley near Debar, Bulletin on the geographical society, XVIII, Beograd, pp 59-77, 1932.

[21] Radovanovik V.S. Sandstone formation with balls-shaped near Ulanci, Bulletin of Scientific Society of Skopje, XVII, Skopje, pp 25-28, 1937.

[22] Schumm, S.A. Geomorphic thresholds: the concept and its applications, Transactions of the Institute of British Geographers, NS4, pp 485-515, 1979.

[23] Sharples, C. Geoconservation in forest management - principles and procedures, Tasforests, Vol. 7, Forestry Tasmania, Hobart, pp 37 - 50, 1995.

[24] Stojadinovil C. Geomorphological research of the gypsum relief in the valley of Radika, Annual proceedings of the Faculty of Philosophy, book 11, Skopje, pp 75-86, 1953.

[25] Stojmilov A. Geography of the Republic of Macedonia, Skopje, pp 206, 2011.

[26] Todorova A., Kolchakovski D., Dimitrovska O., Milevski I. Protection and presentation of the "Pillow Lava" site near the village of Miravci, Geographical Reviews, Skopje, no. 49, pp. 512, 2016.

[27] Velev J, Mitković P., Dinić M., Bogdanović I. Sustainable development of the protected areas with the reference to the Sicevo George, Facta Universitatis, Series: Architecture and Civil Engineering, Vol. 6, № 2; Niš, 2008.

[28] Weighell, T. National and international strategies for the integration of geological and nature conservation, Abstracts of the 31st International Geological Congress, Rio de Janeiro, 2000. 